\title{
Optimization of the process of efficiency management of the primary kaolin excavation on the curved face of the conditioned area
}

The Mining-Geology-Petroleum Engineering Bulletin UDC: $622: 271$

DOI: 10.17794/rgn.2020.1.10

Original scientific paper

\author{
Ruslan Sobolevskyi ${ }^{1}$; Valentyn Korobiichuk'; Volodymyr Levytskyi'; Victor Pidvysotskyi ${ }^{1}$; \\ Oleksandr Kamskykh'; Liudmyla Kovalevych',
}

${ }^{1}$ Faculty of Mining and Ecology, Zhytomyr Polytechnic State University, str. Chudnivska 103, 10005, Zhytomyr, Ukraine

\begin{abstract}
The influence of primary kaolin moisture on the duration of bucket unloading is proven, and the analytical dependence for the estimation of this ratio in the form of a second-degree polynomial is obtained. Three main technological schemes for different technological conditions substantiate the procedure for evaluating the productivity of the primary kaolin excavation for cases of selective development of curvilinear sections on the basis of the first proposed technological coefficient of the contact form, which takes into account the fractal nature of the section's shape, are suggested in the article. It is first proposed to include the specific time of shifting in the working cycle of backhoe type excavators. The mathematical models of the primary kaolin excavation process on the curved face of the conditioned area with a backhoe type excavator for different varieties of the mutual arrangement of the hydraulic excavator and the hauler are developed.
\end{abstract}

Keywords:

productivity, efficiency management, excavator, fractal dimension, mathematical model, the process of excavation

\section{Introduction}

The effectiveness of quality management is important for deposits of non-metallic building materials and, in most cases, determines the profitability of the deposit development process. The analysis of approaches to quality management allowed the allocation of the main direction of the research: the development of a methodological basis for decision-making, the measurement and the quality indicator classifications (Manhart, Vogt, et al., 2019; Carabassa, et al., 2019); the assessment of the spatial distribution of quality indicators (Brilli, M., et al., 2018; Taboada, J., et al., 2008; Kapageridis, I., et al., 2016; Sobolevskyi, R., et al., 2016; Golik, V., et al., 2016); justification of the quality management methods at mining on the basis of the technology optimization modeling of deposit development (Cheskidov, V., et al., 2014; Drebenstedt, C., et al., 2013; Kurlenya, M., 1983).

The study of quality indicators is aimed at establishing mineral conditions, and significantly depends on the direction of use and is individual for each particular deposit. The number of quality indicators for a single deposit varies from one to infinity. The choice of indicators should be by priority, which is determined by the expected economic efficiency.

Corresponding author: Volodymyr Levytskyi

v.levytskyi@ztu.edu.ua
The content of certain chemical elements and their compounds is also a common indicator of the quality of deposits of non-metallic building materials. Various industries have different requirements for the quality of raw materials, while harmful impurities for one industry are often the main indicator of the quality for the manufacturing of products in another, and thus, quality management in such cases should ensure maximum consideration of multi-vector requirements, which demands solving a number of complex problems (Chetverik, M., et al., 2013; Azapagic, A., 2004; Grenon, M., Hadjigeorgiou, J., 2010). Thus, in the production of kaolin, modern industrial production is mainly focused on the use of materials with a maximum content of kaolin minerals and a minimum content of quartz, potassium feldspar, mica, minerals and oxides of iron and titanium (Sobolevskyi, R., et al., 2015).

The economic efficiency of kaolin deposit development is largely determined by the perfection of technological solutions and depends on the reliability of the forecast in the design of mining and overburden operations.

As experience in the developing deposits of nonmetallic building materials has shown, the most difficult segment in the design of mining operations is to justify the optimal technological solutions for the development of upper mining horizons, which are characterized by a large number of areas of substandard raw materials or overburden. The need for the selective development of 
the upper horizons significantly reduces the productivity of rock mass excavation. Therefore, the optimization process of kaolin deposit development efficiency management is an important applied research task.

\section{Literature Data Analysis and Target Setting}

In the extraction and processing of minerals, there are many different approaches to the quality management of raw materials. So, the process of operational planning and optimization of daily coal production with the requirements for quality, economic efficiency and technological capabilities are investigated in the paper (Zelensky, A., 2002). A mathematical model of the control volumes of ore extraction in the inter-face mode of averaging using the method of random search is created in the paper (Krasilnikov, A., 2013).

One of the most effective tools of quality management is selective production. The research carried out in this direction is aimed primarily at substantiating optimal technological solutions (Rakishev, B.R., et al., 2000). Thus, the paper (Loginov, E., 2016) substantiates the efficiency of a backhoe type excavator for the selective development of minerals and develops the technique of ledge rational height justification for cases of bottom and top scooping, and also their combination. The study of a backhoe type hydraulic excavator was carried out and the basic dependences for assessing the impact of technological parameters on the performance of the excavation process were obtained in the paper (Kurekhin, E.V., 2009). It proposed to structure the schemes of the faces of the reverse hydraulic bucket in the layered development of ledges behind individual geometrically similar elements in the research (Koryakin, A.I., et al., 2009). The influence of the slope angle of the excavator bottom on the efficiency of the mining process is investigated in the publication (Tyulenev, M.A., et al., 2011).

Much attention is given to research of the mining equipment structural characteristics influence on the effectiveness of the quality management of non-metallic building materials; thus, the paper (Nenashev, A.S., Fedotenko, V.S., 2011) investigates the influence of bucket capacity and a technological scheme on the performance of excavation of a rock mass; but a mathematical model of the rock mass excavation process of a backhoe type excavator to estimate a layer, which is separated by scooping, and the filling ratio of the bucket at different points of the excavator slaughter is developed in the paper (Strelnikov, A.V., Tioulenev, M.A., 2011); while the optimal geometric dimensions of the bucket are proven and the efficiency of a backhoe type excavator when using buckets of various sizes is investigated in the research (Komissarov, A.P., et al., 2006; Pobegailo P.A., 2014). Intensification of technological processes in drilling and blasting operations during open-cut mining and organization of dumping stations with combined transport types are investigated in the publication (Zairov, Sh., et al., 2018; Abdellah, W.R., et al., 2018; Sobko, B., et al., 2017; Shustov, O., Dryzhenko, A., 2016).

\section{Purpose and Objectives of Research}

The purpose is the process of optimization of the efficiency management of the primary kaolin deposit development by a backhoe excavator for cases of curvilinear site selective development.

Objectives:

1) to investigate the influence of the primary kaolin moisture on the duration of bucket unloading;

2) to develop technological schemes for various technological conditions and to justify the procedure for evaluating the performance of the primary kaolin excavation for the cases of selective development of curved sections taking into account the fractal nature of the section's shape;

3) to develop mathematical models of the primary kaolin excavation process on the curved face of the conditioned area by a backhoe type excavator.

\section{Materials and Methods}

It is proposed to determine the optimal values using mathematical analysis and optimization modeling by brute force for the case of ledge rational height justification and for excavator pass width for technological schemes.

It is important to consider the presence of overburden inclusions when evaluating the performance of kaolin excavation.

The analysis of the excavator efficiency use executed at the excavation of breed on the verge of the conditioned site allowed us to establish that the excavator is compelled to carry out additional scooping cycles the quantity of which depend on the perimeter of the conditioned site and wedging depth of overburden breeds in a mineral massif. The use of different schemes of scooping modes can significantly reduce the additional time spent on the selective development of the deposit (see Figure 1).

However, additional cycles of scooping in the contour strip cannot be avoided. Accordingly, the number of additional scooping cycles caused by the presence of overburden inclusions in the excavator pass can be determined from the expression:

$$
N_{a d .}=\frac{B_{s . p .}}{b_{b}} \frac{L_{s . p .}}{l_{t} \cos \beta} \frac{H_{o l}}{l_{t} \sin \beta}+\frac{P_{c a} H_{o l}}{n_{e . b} b_{b} l_{t} \sin \beta},
$$

where:

$B_{s, p .}, L_{s . p .}$ - the width and length of the substandard part of the site, which are defined as the sum of the arithmetic means within the excavator unit (m), respectively; 


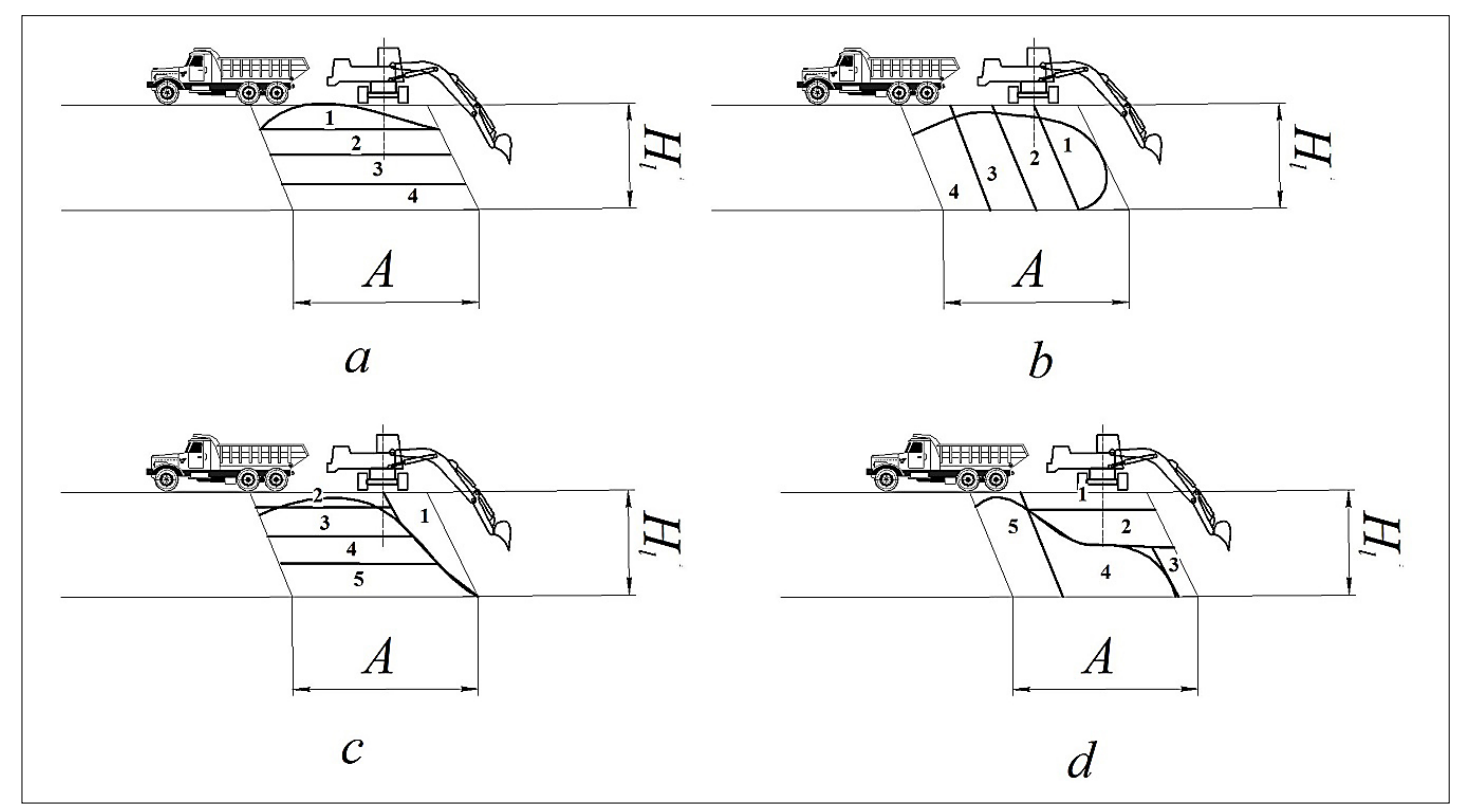

Figure 1: Schemes of scooping modes at selective development of the primary kaolin (numbers $1-5$ are an excavation order of kaolin)

$\beta$ - the angle of ledge slope (deg.);

$b_{b}-$ the bucket width $(\mathrm{m}) ; l_{t}-$ the bucket trajectory length, when scooping (m);

$n_{\text {e.b. }}-$ the number of excavator blocks required for the development of the conditioned area (pcs.);

$P_{c a}$ - the perimeter of the conditioned area (m);

$H_{o l}$ - the height of the overburden layer on the conditioned area $(\mathrm{m})$.

In this expression, the first part corresponds to the number of cycles made in the off-grade part due to the need of excavation of overburden, and the second part corresponds to the additional cycles of excavator scooping stipulating the necessity of the need for delineated standard quality parts of an excavator pass.

Accordingly, the effect of additional cycles on the duration of a single cycle is proposed to determine from the expression:

$$
T_{a d .}=\frac{N_{a d} T_{w . c .}}{N_{t o t}}
$$

where:

$N_{\text {tot. }}$ - the total number of cycles in the selective development of the excavator unit (pcs);

$N_{a d}$ - the total number of additional cycles (pcs);

$T_{w c}$ - the estimated duration of the excavator working cycle depending on the type of rocks being developed and the angle of excavator rotation to discharge (hours);

$$
N_{t o t}=\frac{A H_{l} L_{e . b .} k_{l . r .}}{E k_{f . b .}},
$$

where:

$A$ - the width of the setting for backhoe type excavator is determined from the expression (m);

$$
H_{l} \text { - the height of the ledge (m); }
$$

$L_{\text {e.b. }}$ - the length of the excavator block (m);

$K_{l r}$ - the coefficient of loosening of the rock in the bucket

$K_{f b}$ - the coefficient of filling the bucket.

After substitution and abbreviations, we get the expression:

$$
T_{a d .}=\left(\frac{B_{s . p .}}{b_{b}} \frac{L_{s . p .}}{l_{t} \cos \beta} \frac{H_{o l}}{l_{t} \sin \beta}+\frac{P_{c a} H_{o . l} E k_{f . b .}}{b_{b} l_{t} \sin \beta n_{e . b .} A H_{l} L_{e . b .} k_{l . r .}}\right) T_{w . c^{*}} .
$$

Considering the greater prevalence in the practice of design calculations of the values of conditioned areas as well as their fractal nature and the results of previous studies, the dependence (14) can be written in this form:

$$
T_{a d .}=\left(\frac{B_{s . p .}}{b_{b}} \frac{L_{s . p .}}{l_{t} \cos \beta} \frac{H_{o l}}{l_{t} \sin \beta}+\frac{e^{\frac{\ln (S)}{D_{f}}} H_{o l} E K_{f . b .}}{b_{b} l_{t} \sin \beta n_{e . b .} A H_{l} L_{e . b .} k_{l . r .}}\right) T_{w . c .},
$$

where:

$D_{f}$ - the index of fractal dimension of the area line;

$S-$ the area of the quality standard area $\left(\mathrm{m}^{2}\right)$.

For convenience of calculations it is offered to enter technological coefficient of the contact form:

$$
k_{f . c .}=\frac{B_{s . p .}}{b_{b}} \frac{L_{s . p .}}{l_{t} \cos \beta} \frac{H_{o l}}{l_{t} \sin \beta}+\frac{e^{\frac{\ln (S)}{D_{f}}} H_{o l} E K_{f . b .}}{b_{b} l_{t} \sin \beta n_{e . b .} A H_{l} L_{e . b .} k_{l . r .}}
$$

To optimize the process of managing the efficiency of the development of the primary kaolin deposits, the objective function will generally have the following form:

$$
P_{\text {e.w.sh. }}=f\left(\begin{array}{c}
E, H_{l}, H_{t}, b_{b}, R_{d}, R_{\text {dis }}, B_{a}, A, c, L_{e . b .}, \\
k_{f . k .}, t_{l b}, v_{\text {low.b. } .}, v_{\text {s.e. }}, v_{\text {b.l. }}, v_{\text {l.r. }}, l_{t s}, v_{\text {e.r. }}
\end{array}\right) \rightarrow \max .
$$

where: 
$P_{\text {e.wsh }}$ - the performance of the excavator ( $\left.\mathrm{m}^{3} / \mathrm{w} . \mathrm{shift}\right)$;

$E$ - the excavator bucket capacity $\left(\mathrm{m}^{3}\right)$;

$H_{1}$ - the height of the ledge (m);

$H_{t}$ - the haul truck height (m);

$b_{b}$ - the bucket width (m);

$R_{d}$ - the radius of the excavator digging (m);

$R_{\text {dis }}$ - the excavator discharge radius (m);

$B_{a}$ - the haul truck width (m);

$A$ - the width of the setting for backhoe type excavator is determined from the expression (m);

$c$ - the gap between the back of a haul truck and a bucket $(\mathrm{m})$;

$L_{e . b .}$ - the length of the excavator block (m);

$k_{\text {f.c. }}$ the coefficient of the contact form;

$t_{l b}$ - time of loading bucket (sec);

$v_{\text {low. } . \text {. }}-$ the speed of lowering the bucket into the face $(\mathrm{m} / \mathrm{sec})$; sec);

$v_{\mathrm{se}}-$ the speed of the working excavator shifting $(\mathrm{m} /$

$v_{b l}$ - the bucket lifting speed $(\mathrm{m} / \mathrm{sec})$;

$v_{l, .}$ - the speed of loaded bucket rotation (deg./sec);

$v_{e . r}-$ the speed of empty bucket rotation (deg./sec).

$l_{t s}$ - the bucket trajectory length, when scooping (m);

At the same time the main restrictions are accepted:

$$
1 \leq b_{b} \leq \frac{E}{h b},
$$

where:

$h, b$ - respectively the height and width of the bucket (m).

$$
0 \leq H_{r o z v} \leq H_{t}+c
$$

where:

$H_{\text {rozv }}$ - the maximum unloading height of the excavator (m);

$c$ - the gap between the back of a haul truck and a bucket (m);

$H_{t}-$ the haul truck height (m).

$$
\begin{aligned}
0,75 R_{d} & \leq A \leq 1,75 R_{d} ; \\
1 & \leq c ; \\
2 \leq H_{l} & \leq H_{k o p \text {.max. }}
\end{aligned}
$$

where:

$R_{d}$ - the radius of the excavator digging (m);

$H_{l}$ - the height of the ledge (m);

$H_{\text {max.d. }}$ - maximum digging height (m).

Accordingly, it is necessary to find the function extreme values at specified intervals and, using linear programming methods, to find the optimal values of the parameters.

The optimal parameter values will be in sequential choice of optimal parameters for a given interval of the following system of equations of the following form for three technological schemes: for the case of justification of the rational height of the ledge and for excavator pass width.

To study the ways of optimizing the influence of the shape and size of the excavator block, the target function was obtained:

$$
\left\{\begin{array}{l}
k_{f . c .} \rightarrow \min \\
2 \leq H_{o . l .} \leq H_{l .} \\
1 \leq b_{b} \leq \frac{E}{h b} \\
0 \leq B_{s . p .} \leq A
\end{array}\right.
$$

Optimal parameter values in sequential choice of optimal heights of the ledges and for excavator passes width for given intervals were obtained for the three technological schemes.

The resulting model will allow the choosing of the optimal values of technological parameters for different areas, depending on the value of the technological coefficient of the contact form. Visual representations of model equations were developed using Maple 2015 (Maplesoft).

The influence of humidity of the primary kaolin of Veliko-Gadominetsky deposit on the duration of bucket unloading of $345^{\circ} \mathrm{C}$ excavators with a Cat NACD bucket was investigated. The methodology of the study was a preliminary measurement of humidity with a moisture meter MS-360XLA in three places at different heights for a zone that corresponds to the width of the bucket. As a part of the studies, a Canon 7000D digital camera was used for timing.

\section{Research of Efficiency Process of Curvilinear Sites Selective Development by a Backhoe Type Excavator}

To a large extent, the efficiency of an excavator depends on the compliance of the selected option of sinking mining and geological conditions and technical capabilities of the excavator and can be estimated by the performance values. The variable operating performance can be determined from the expression according to the classical approach for determining the performance of the excavator:

$$
P_{e . w . s h}=\frac{E K_{e} K_{b} K_{e . u} T_{w . s h}}{T_{w c}}, \mathrm{~m}^{3} / \mathrm{w} \cdot \mathrm{shift},
$$

where:

$E$ - excavator bucket capacity $\left(\mathrm{m}^{3}\right)$;

$K_{e}$ - the coefficient of excavation;

$K_{b}$ - a bottom-hole ratio, taking into account the impact of auxiliary operations $(0.85-0.9)$; 
$T_{w . c}$ - the estimated duration of the excavator working cycle depending on the type of rocks being developed and the angle of excavator rotation to discharge (hours);

$T_{w . s h}$ - a work shift duration (hours);

$K_{e . u}$ the coefficient of excavator using in time.

There are many different approaches to determining the duration of the backhoe type excavator's working cycle. It should be noted that this parameter depends on the following factors: technological (technological scheme, type and parameters of the face, the method of unloading the rock), personal (operator qualification and motivation), mining and geological (rock type, the thickness of the mineral and rocks in which there are separate areas of minerals, the parameters of mineral layer occurrences, hydrogeological conditions). A large number of factors make it necessary to individualize approaches in determining productivity for specific mining and geological conditions and technological solutions.

Taking into account the results of studies (Koryakin, A.I., et al., 2009; Tyulenev, M. A., et al., 2011; Nenashev, A.S., Fedotenko, V.S., 2011; Strelnikov, A.V., Tioulenev, M.A., 2011) and the experience of this type of excavator's operation, it is proposed to determine the duration of the cycle for the case of unloading in a dump truck, which is located on the excavator horizon, from the following expression:

$$
\begin{gathered}
T_{w . c .}=\frac{H_{l}+H_{t}+c}{v_{l o w b}}+t_{l b}+\frac{H_{l}+H_{t}+c-l_{t} \sin \beta}{v_{b l}}+ \\
+\frac{\alpha_{l, r .}}{v_{l r}}+\frac{\alpha_{e . r .}}{v_{e r}}+t_{u n}, \mathrm{sec} .
\end{gathered}
$$

where:

$H_{l}$ - the ledge height (m);

$H_{t}$ - the haul truck height (m);

$c$ - the gap between the back of a haul truck and a bucket (m);

$t_{l b}$ - time of loading bucket (sec);

$v_{\text {low. } . \text {. }}-$ the speed of lowering the bucket into the face $(\mathrm{m} / \mathrm{sec})$;

$l_{t s}$ - the bucket trajectory length, when scooping $(\mathrm{m})$;

$\beta$ - the angle of ledge slope (deg.);

$v_{b l}$ - the bucket lifting speed $(\mathrm{m} / \mathrm{sec})$;

$\alpha_{l . . .}-$ the angle of loaded bucket rotation (deg.);

$v_{l, r}$ - the speed of loaded bucket rotation (deg./sec);

$\alpha_{e, r}-$ the angle of empty bucket rotation (deg).;

$v_{e, r}-$ the speed of empty bucket rotation (deg./sec);

$t_{u n}$ - unloading time (sec).

When determining the angle of the rotation of the excavator, a value is used that corresponds to the angle between the radius of unloading and scooping, for the case when the axis of the excavator is oriented parallel to the axis of the face. This approach allows for the obtaining of an approximate estimate of the turn angle effect on the performance of the excavator that is due to the fact that the excavator rotates from the place of digging to the point of unloading from a starting angle other than zero and depends on the width of the excavator bucket cutting edge. This fact allows us to determine the angle of the excavator rotation to use the expression:

$$
\alpha_{s r}=\arcsin \left(\frac{A}{2 R_{d}}\right)+2 \arcsin \left(\frac{0,5 B_{t}+L_{b t}}{2 R_{d i s}}\right),
$$

where:

$R_{d}$ - the radius of the excavator digging (m);

$R_{\text {dis }}$ - excavator discharge radius (m);

$B_{t}$ - the haul truck width (m);

$L_{b t}$ - the distance from top of berm to haul truck (m);

$A$ - the width of the setting for backhoe type excavator is determined from the expression $(\mathrm{m})$ :

$$
A=\sqrt{R_{g l}^{2}-l_{s h}^{2}},
$$

$R_{g l}-$ the radius of the excavator digging on grade level (m);

$l_{s h}$ - the length of the working excavator shifting (m).

The disadvantage of this approach is that it does not take into account the width of the bucket, which technically determines the width of the pass, respectively, with this approach, the width of the pass will be:

$$
A=b_{b} n_{b p}
$$

$n_{b p}$ - the whole number of buckets in a pass (pcs);

$b_{b}$ - the bucket width (m).

Accordingly, the requirements for the multiplicity factor of the pass width to the bucket width will lead to the following system

$$
\left\{\begin{array}{l}
A=b_{b} n_{b p} \\
A=\sqrt{R_{g l}^{2}-l_{s h}^{2}} .
\end{array}\right.
$$

Such an approach will allow us to increase the reliability of the forecast of excavation productivity.

This paper deals with the most typical variants of technological schemes that are appropriate to use in the development of primary kaolin. The most common option is to use an excavator with a bottom scoop and unload the rock mass into a haul truck, which is located at the excavator grade level (see Figure 2).

An important factor determining the performance of rock mass excavation is the time spent on excavator movement. In accordance with the classical approach to determining the excavator length, the shifting time of the excavator in terms of one cycle can be determined from the expression:

$$
t_{\text {s.e. }}=\frac{l_{\text {sh }}}{v_{\text {s.e. }} N_{s}},
$$

where:

$l_{s h}-$ the length of the working excavator shifting (m); 

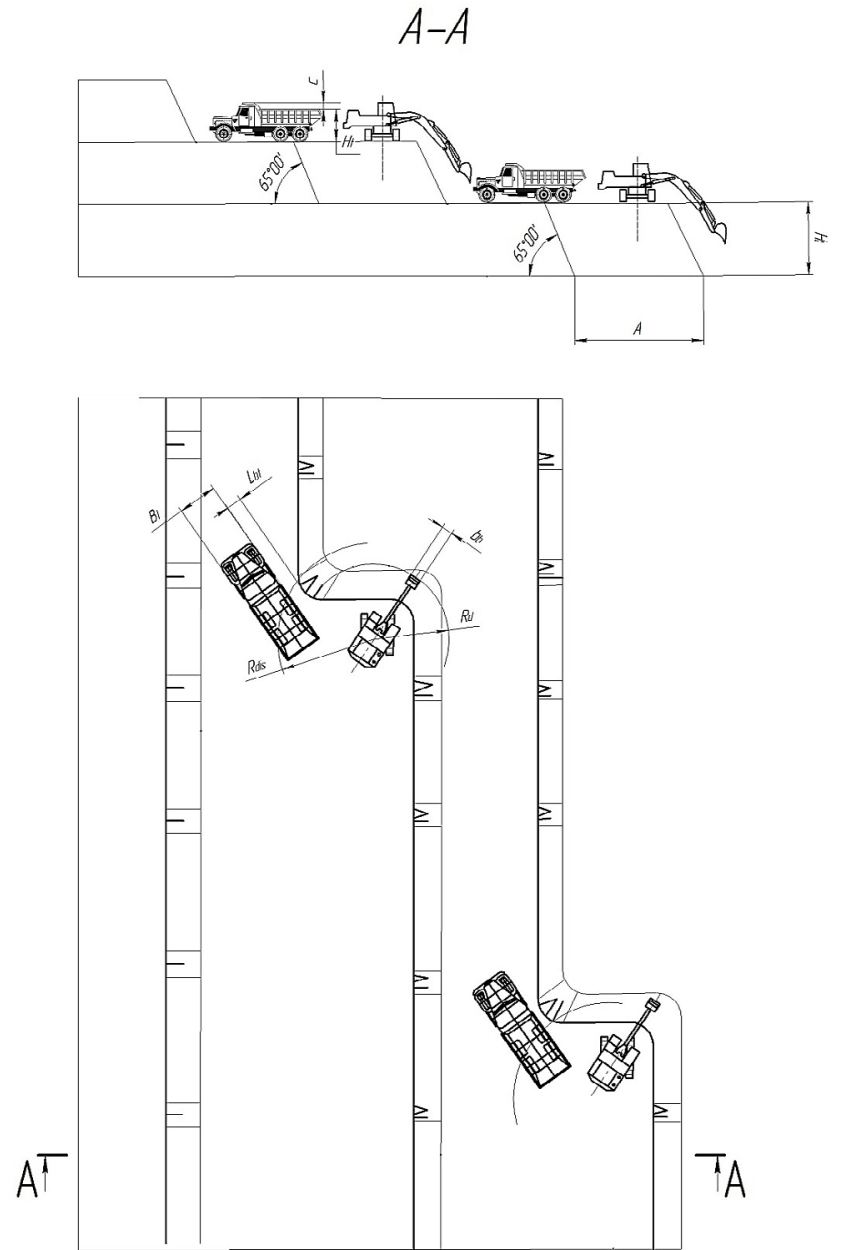

Figure 2: The technological scheme of the selective development using a backhoe type excavator with lower scoops and unloading of rock mass into a haul truck, which is located at the excavator grade level (Scheme 1) $v_{\mathrm{se}}-$ the speed of the working excavator shifting $(\mathrm{m} /$ $\sec )$;

$N_{s}-$ the number of excavator cycles for one shift (pcs).

where:

$$
N_{s}=\frac{l_{s h} A H_{l} k_{l . r .}}{E k_{f . b .}},
$$

$l_{s h}$ - the length of the working excavator shifting (m);

$A$ - the width of the setting for backhoe type excavator $(\mathrm{m})$;

$H_{l}$ - the ledge height $(\mathrm{m})$;

$k_{l r}-$ the coefficient of loosening of the rock in the bucket;

$E$ - excavator bucket capacity $\left(\mathrm{m}^{3}\right)$;

$k_{f b}$ - the coefficient of filling the bucket.

Therefore, in the general case of the kaolin deposits development for straight sections, the working cycle duration is proposed to be determined from the expression:

$$
\begin{aligned}
& T_{\text {w.c. }}=\frac{H_{l}+H_{t}+c}{v_{\text {low.b. }}}+t_{l . b .}+\frac{H_{l}+H_{t}+c-l_{t} \sin \beta}{v_{b l}}+ \\
& +\frac{\arcsin \left(\frac{i b_{b a b}}{2 R_{d}}\right)+2 \arcsin \left(\frac{0,5 B_{t}+L}{2 R_{d i s}}\right)}{v_{l . r .}}+ \\
& +\frac{\arcsin \left(\frac{i b_{b a b}}{2 R_{d}}\right)+2 \arcsin \left(\frac{0,5 B_{t}+L}{2 R_{\text {dis }}}\right)}{v_{\text {e.r. }}}+\frac{E k_{f . b .}}{v_{\text {s.e. }} A H_{l} k_{l . r .}}+t_{u n} .
\end{aligned}
$$

where:

$B_{t}-$ the haul truck width (m);

$L_{b t}$ - the distance from the top of berm to haul truck

\begin{tabular}{|c|c|c|c|c|c|c|c|c|c|c|c|c|c|c|}
\hline 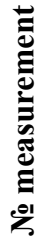 & 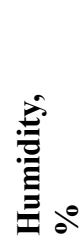 & 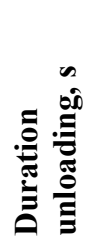 & 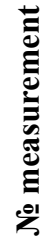 & 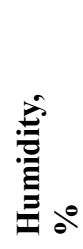 & 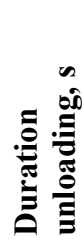 & 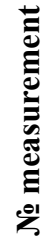 & 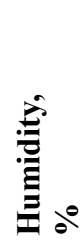 & 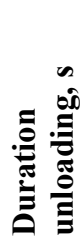 & 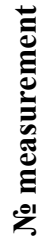 & 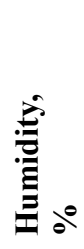 & 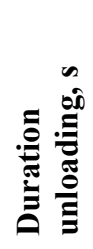 & 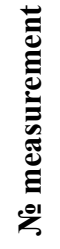 & 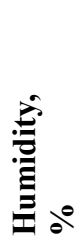 & 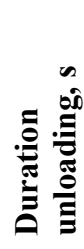 \\
\hline 1 & 10.1 & 1.2 & 11 & 12.6 & 1.7 & 21 & 18.3 & 1.2 & 31 & 28.4 & 2.8 & 41 & 22.6 & 2.7 \\
\hline 2 & 10.2 & 1.5 & 12 & 12.7 & 1.3 & 22 & 19.4 & 2.1 & 32 & 29.3 & 3.4 & 42 & 22.8 & 2.6 \\
\hline 3 & 10.7 & 1.3 & 13 & 13 & 1.5 & 23 & 20.1 & 1.7 & 33 & 30.1 & 3.1 & 43 & 22.3 & 3.4 \\
\hline 4 & 10.2 & 1.1 & 14 & 13.5 & 1.1 & 24 & 21.3 & 1.9 & 34 & 30.2 & 3.5 & 44 & 22.9 & 3.2 \\
\hline 5 & 11.0 & 1.2 & 15 & 14.2 & 1.4 & 25 & 22.4 & 2.2 & 35 & 32.4 & 3.7 & 45 & 23.4 & 2.9 \\
\hline 6 & 11.3 & 1.1 & 16 & 14.7 & 1.2 & 26 & 23.4 & 2.4 & 36 & 35 & 4.4 & 46 & 26.7 & 2.8 \\
\hline 7 & 11.4 & 1.2 & 17 & 13.2 & 1.3 & 27 & 24.2 & 2.7 & 37 & 34.9 & 3.8 & 47 & 22.7 & 2.7 \\
\hline 8 & 11.8 & 1.8 & 18 & 15.3 & 1.2 & 28 & 25.6 & 2.3 & 38 & 35.6 & 4.5 & 48 & 23.9 & 2.8 \\
\hline 9 & 12.0 & 1.4 & 19 & 16.4 & 1.5 & 29 & 26.3 & 2.9 & 39 & 32.6 & 3.9 & 49 & 24.3 & 3.1 \\
\hline 10 & 12.4 & 1.2 & 20 & 17.8 & 1.9 & 30 & 27.2 & 2.7 & 40 & 30.3 & 3.1 & 50 & 26.4 & 4.2 \\
\hline
\end{tabular}
(m);

$t_{u n}$ - unloading time ( $\left.\mathrm{sec}\right)$.

Table 1: The results of measuring the cycle duration for different humidity effects 
The results of studies of humidity effect on the bucket unloading duration of Caterpillar $345 \mathrm{C}$ excavator with a Cat NACD bucket are shown in Table 1.

This paper is investigating the dependence of the contact form technological coefficient for the 282-286-10 area according to Figure 3.

Excavator performance of a backhoe type in the development of curved conditioned kaolin areas placed in overburden rocks is proposed to be determined from the expression $\left(\mathrm{m}^{3} / \mathrm{WM}\right.$.):

$$
\begin{aligned}
& P_{\text {e.w.s. }}=\frac{3600 E k_{e} k_{b} T_{\text {w.h. }} k_{\text {e.u. }}}{\left(\frac{H_{l}+H_{t}+c}{v_{\text {low.b. }}}+t_{l b}+\frac{H_{l}+H_{t}+c-l_{t} \sin \beta}{v_{b l}}+\frac{\arcsin \left(\frac{A}{2 R_{d}}\right)+2 \arcsin \left(\frac{0,5 B_{t}+L_{b t}}{2 R_{\text {dis }}}\right)}{v_{l . r .}}+,\right.}, \\
& \left.+\frac{\arcsin \left(\frac{A}{2 R_{d}}\right)+2 \arcsin \left(\frac{0,5 B_{t}+L_{b t}}{2 R_{d i s}}\right)}{v_{\text {e.r. }}}+\frac{E k_{f . b .}}{v_{p . e .} A H_{l} k_{l . r .}}+t_{u n}\right)\left(1+k_{f . c .}\right)
\end{aligned}
$$

where:

$E$ - the excavator bucket capacity $\left(\mathrm{m}^{3}\right)$;

$K_{e}$ - the coefficient of excavation;

$K_{b}-$ a bottom-hole ratio, taking into account the impact of auxiliary operations (0.85-0.9);

$T_{w . c}$ - the estimated duration of the excavator working cycle depending on the type of rocks being developed and the angle of excavator rotation to discharge (hours);

$T_{w . s h}$ - a work shift duration (hours);

$K_{e . u}-$ the coefficient of excavator using in time.

The most promising from the point of view of the working cycle duration is the option with the lower unloading in the haul truck, the implementation of which is presented for the second technological scheme in Figure 4.

When using the second technological scheme, the performance of the primary kaolin excavation can be determined from the expression:

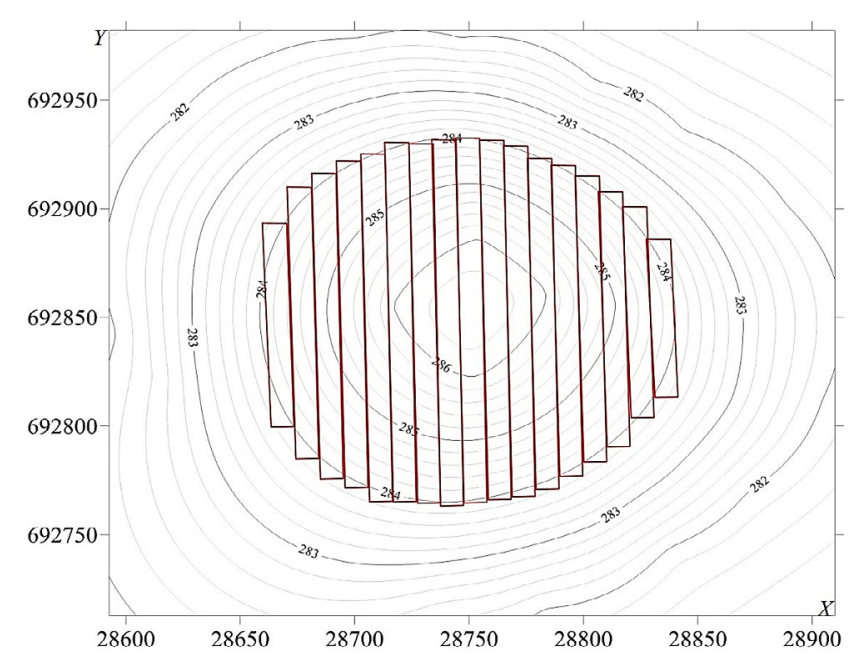

Figure 3: The scheme of the excavator location passes in the development of conditioned areas of the primary kaolin 282-286-10: $\square$ - design lines of the excavator unit
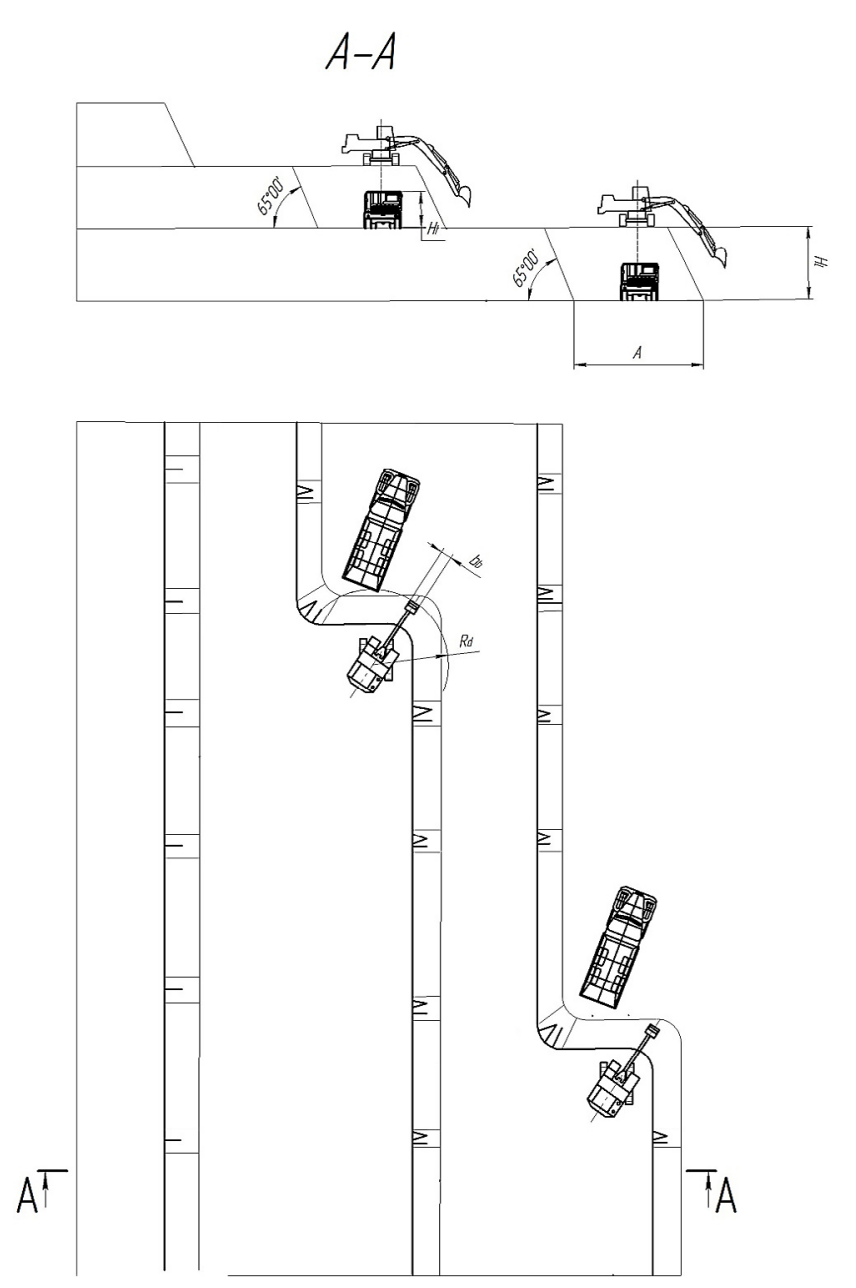

Figure 4: The technological scheme of the selective development using a backhoe type excavator with lower scoops and lower unloading (Scheme 2) 


$$
\begin{aligned}
P_{e . z m .}= & \frac{3600 E k_{e} k_{s} T_{w . s h .} k_{e . u .}}{\left(\frac{H_{l}+H_{t}+c}{v_{l o w . b .}}+t_{l b}+\frac{H_{l}+H_{t}+c-l_{t} \sin \beta}{v_{b l}}+\frac{\arcsin \left(\frac{A}{2 R_{d}}\right)}{v_{l . r .}}+\right.} \\
& \left.+\frac{\arcsin \left(\frac{A}{2 R_{d}}\right)}{v_{e . r .}}+\frac{E k_{l . r .}}{v_{p . e .} A H_{u} k_{f . b .}}+t_{u n}\right)\left(1+k_{f . c .}\right)
\end{aligned}
$$

It should be noted that the considered options for using the backhoe type excavator have proven their effectiveness in the development of the main part of the conditioned area. In the work of the excavator in a contact zone of mineral and rocks, in order to ensure uniformity in working off of a face, it is expedient to use the technological scheme with the top unloading containing rocks and the bottom unloading of mineral (see Figure 5).

For such a technological scheme, the performance of the excavator is proposed to be determined from the expression:

$$
\begin{aligned}
& P_{e . z m}=\frac{3600 E k_{e} k_{b} T_{w . s h .} k_{e . u .}}{\left(\frac{H_{l}+H_{t}+c}{v_{l o w . b}}+t_{l b}+\frac{H_{l}+H_{t}+c-l_{t} \sin \beta}{v_{b l}}+\left(\frac{\arcsin \left(\frac{A}{2 R_{d}}\right)+2 \arcsin \left(\frac{0,5 B_{t}+L_{b t}}{2 R_{\text {dis }}}\right)}{v_{l . r .}}+\right.\right.} \\
& \left.+\frac{\arcsin \left(\frac{A}{2 R_{d}}\right)+2 \arcsin \left(\frac{0,5 B_{t}+L_{b t}}{2 R_{d i s}}\right)}{v_{\text {pov.p. }} A H_{l}}\right) \frac{n_{c}^{u}}{n_{c}}+\left(\frac{\arcsin \left(\frac{A}{2 R_{d}}\right)}{v_{l . r .}}+\frac{\arcsin \left(\frac{A}{2 R_{d}}\right)}{v_{\text {e.r. }}}\right) \frac{n_{c}^{l}}{n_{c}}+ \\
& \left.+\frac{E k_{f . b .}}{v_{\text {s.e. }} A H_{l} k_{l . r .}}+t_{u n}\right)\left(1+k_{f . c .}\right)
\end{aligned}
$$

where: $n_{c}^{u}, n_{c}^{l}-$ the number of cycles accordingly with the upper and lower unloading within one shifting according to the scheme of scooping modes (pcs);

$n_{c}$ - the total number of cycles of excavation within one shifting according to the scheme of modes of scooping (pcs).

The peculiarity of this scheme is a significant reduction in the influence of the form of conditioned areas on the performance of excavation due to the fact that the excavation of overburden and loading into vehicles is carried out parallel to the main production processes. According to this technological scheme, it is advisable to determine the technological coefficient of the contact form from the expression:

$$
k_{f . c .}=\frac{e^{\frac{\ln (S)}{D_{f}}} H_{o l} E k_{f . b .}}{b_{b} l_{t} \sin \beta n_{e . b .} A H_{l} L_{e . b .} k_{l . r .}} .
$$

Figure 5: The technological scheme of selective development using a backhoe type excavator with unloading of the host rocks at the level of the excavator and the lower unloading of the mineral (Scheme 3)
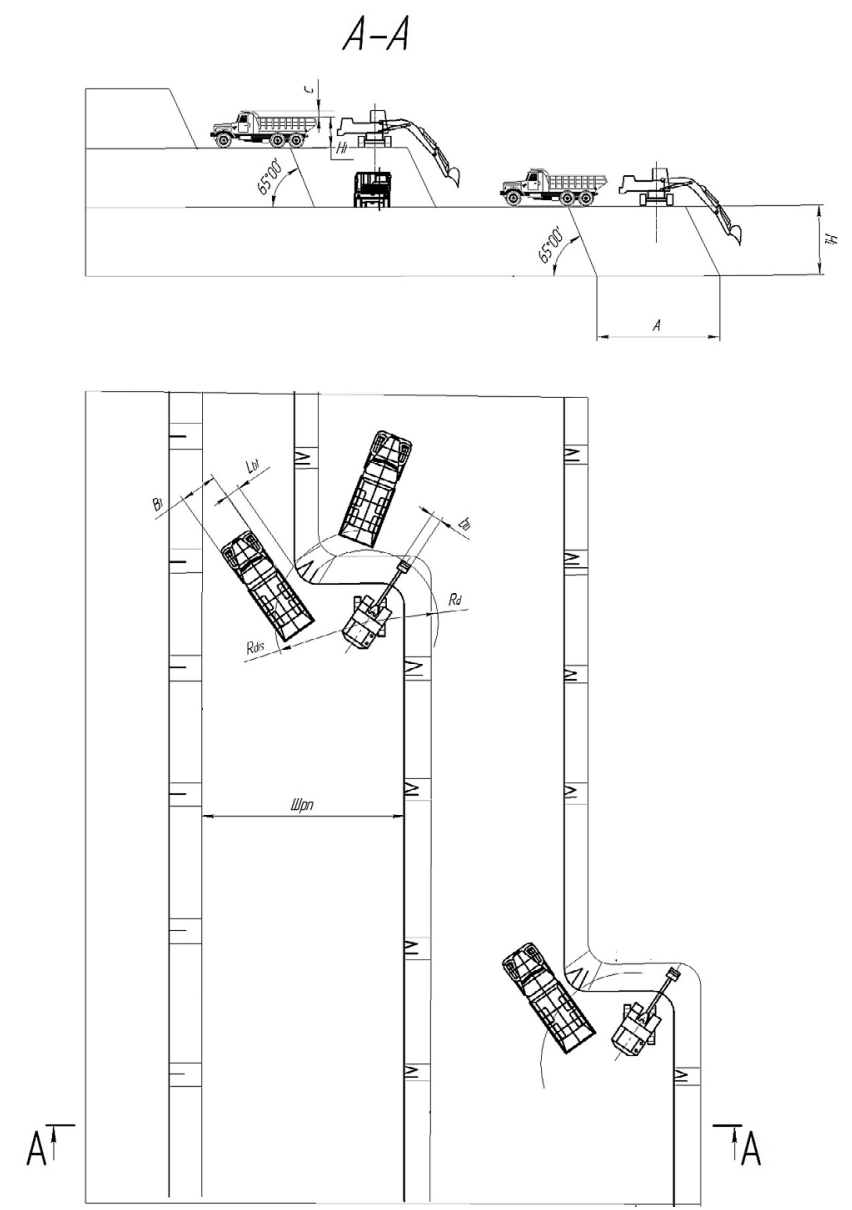
Accordingly, the optimal parameter values will be in the sequential choice of optimal parameters for a given interval of the following system of equations of the following form for the first technological scheme:

1) for the case of justification of the rational height of the ledge:

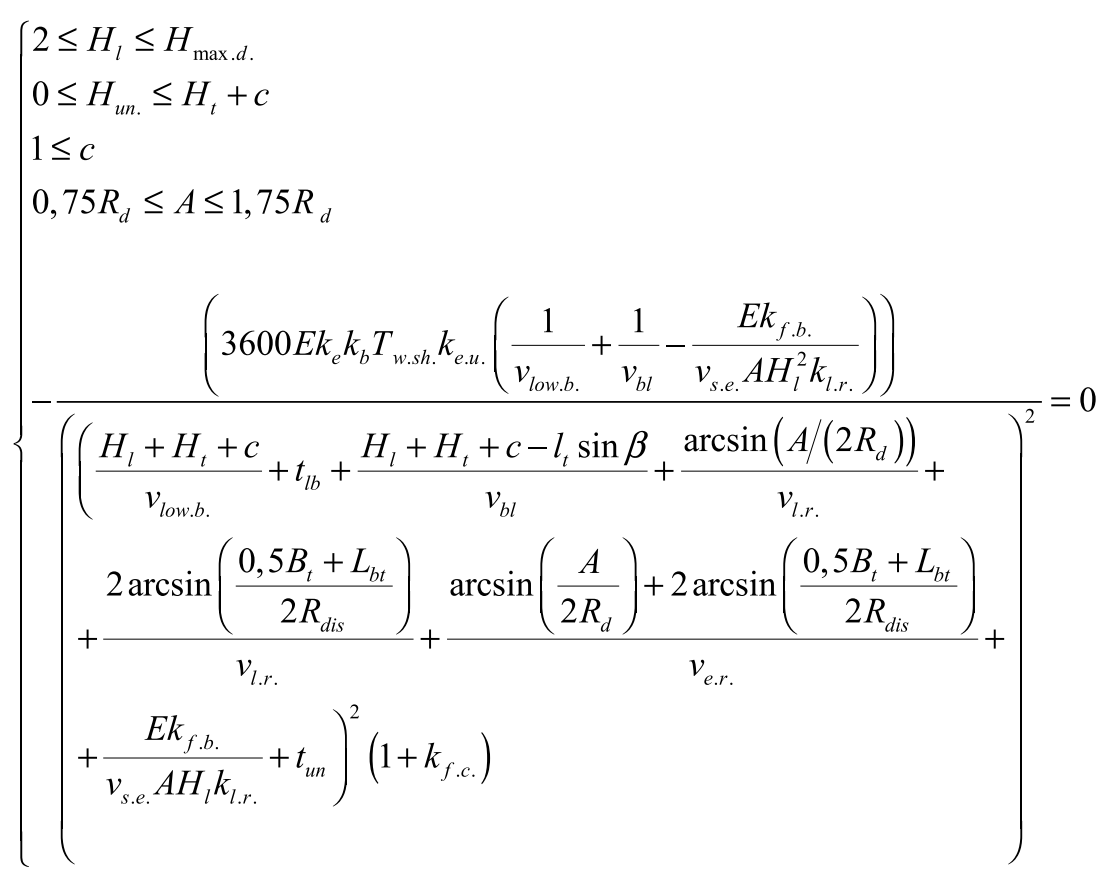

2) for excavator pass width:

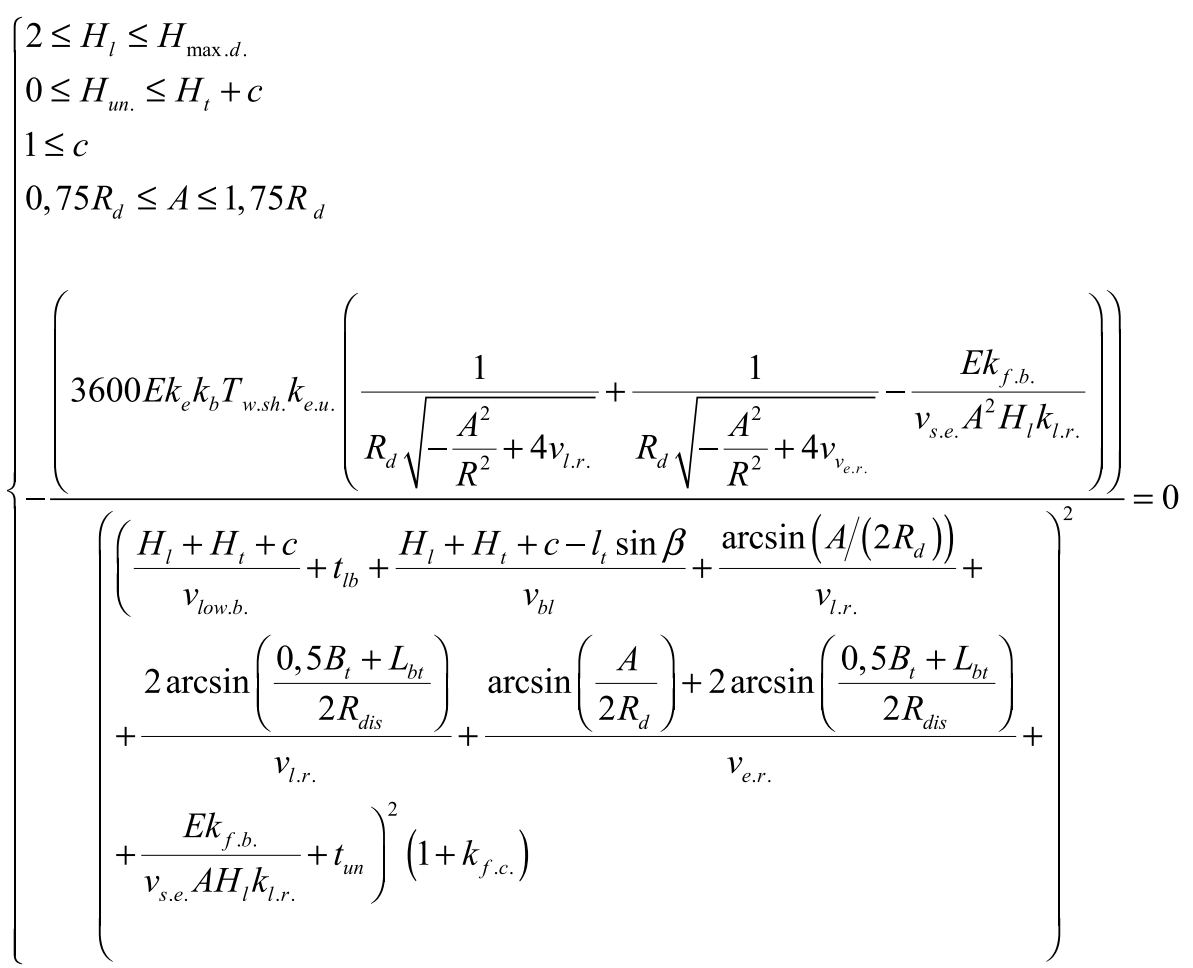


It is proposed to determine the optimal parameter values using mathematical analysis and optimization modeling by brute force for the second technological scheme:

1) for the case of justification of the rational height of the ledge:

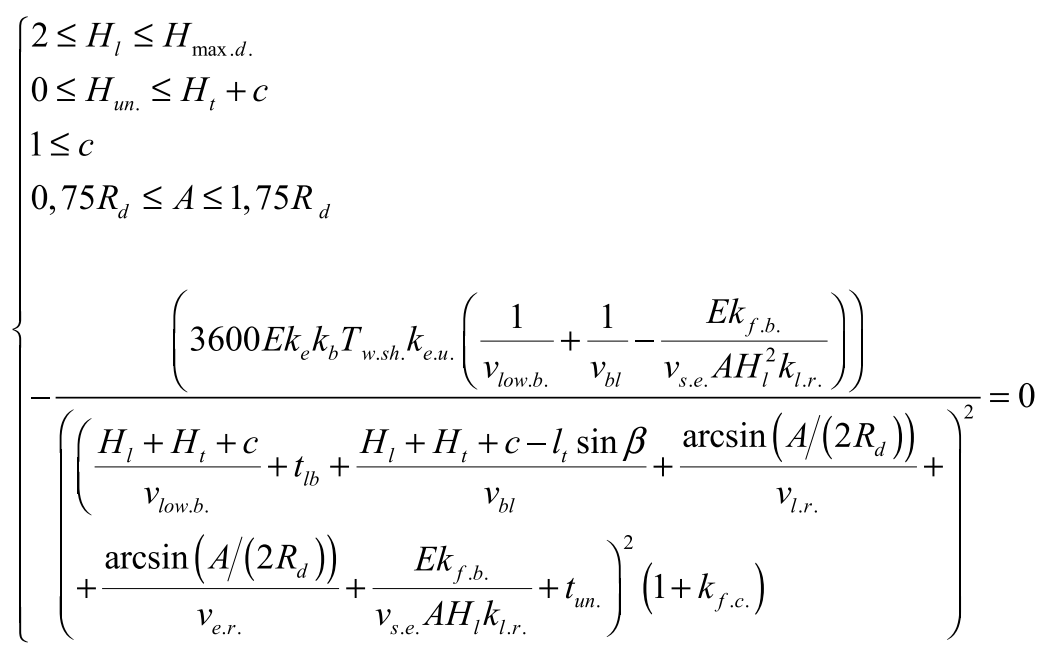

2) for excavator pass width:

$$
\begin{aligned}
& \left\{\begin{array}{l}
2 \leq H_{l} \leq H_{\max . d .} \\
0 \leq H_{u n .} \leq H_{t}+c \\
1 \leq c \\
0,75 R_{d} \leq A \leq 1,75 R_{d}
\end{array}\right.
\end{aligned}
$$

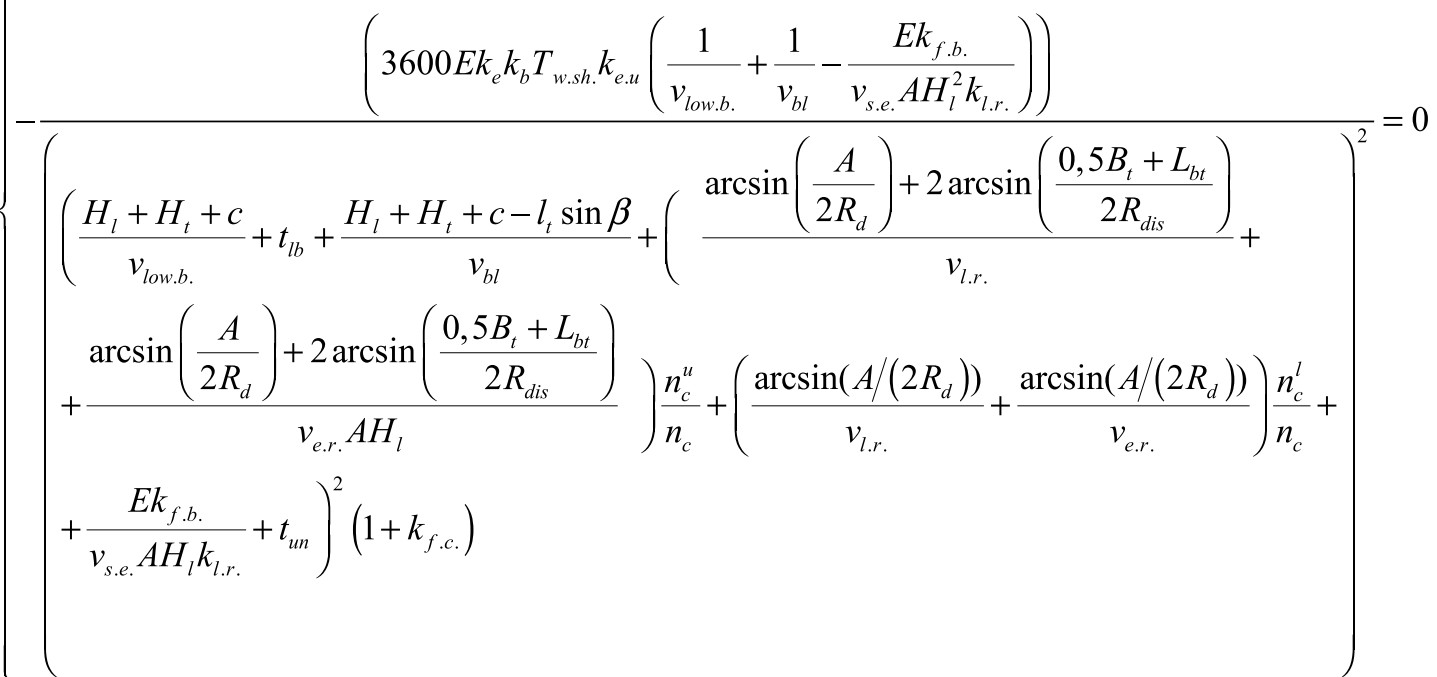


The selection of the optimal parameter values will be carried out similarly in the first two schemes on the set intervals from the equations for the third technological scheme:

1) for the case of justification of the ledge rational height:

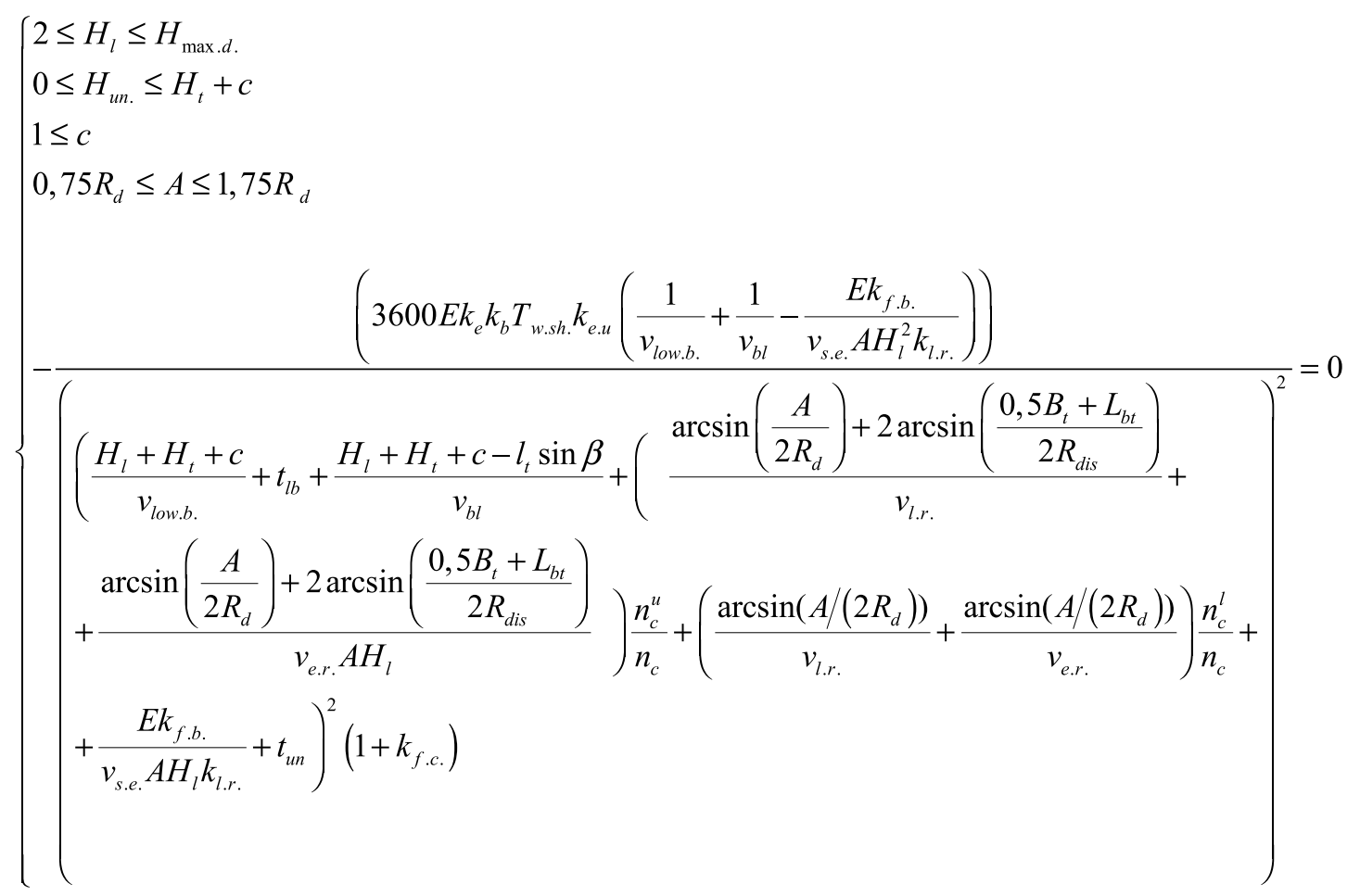


2) for excavator pass width:

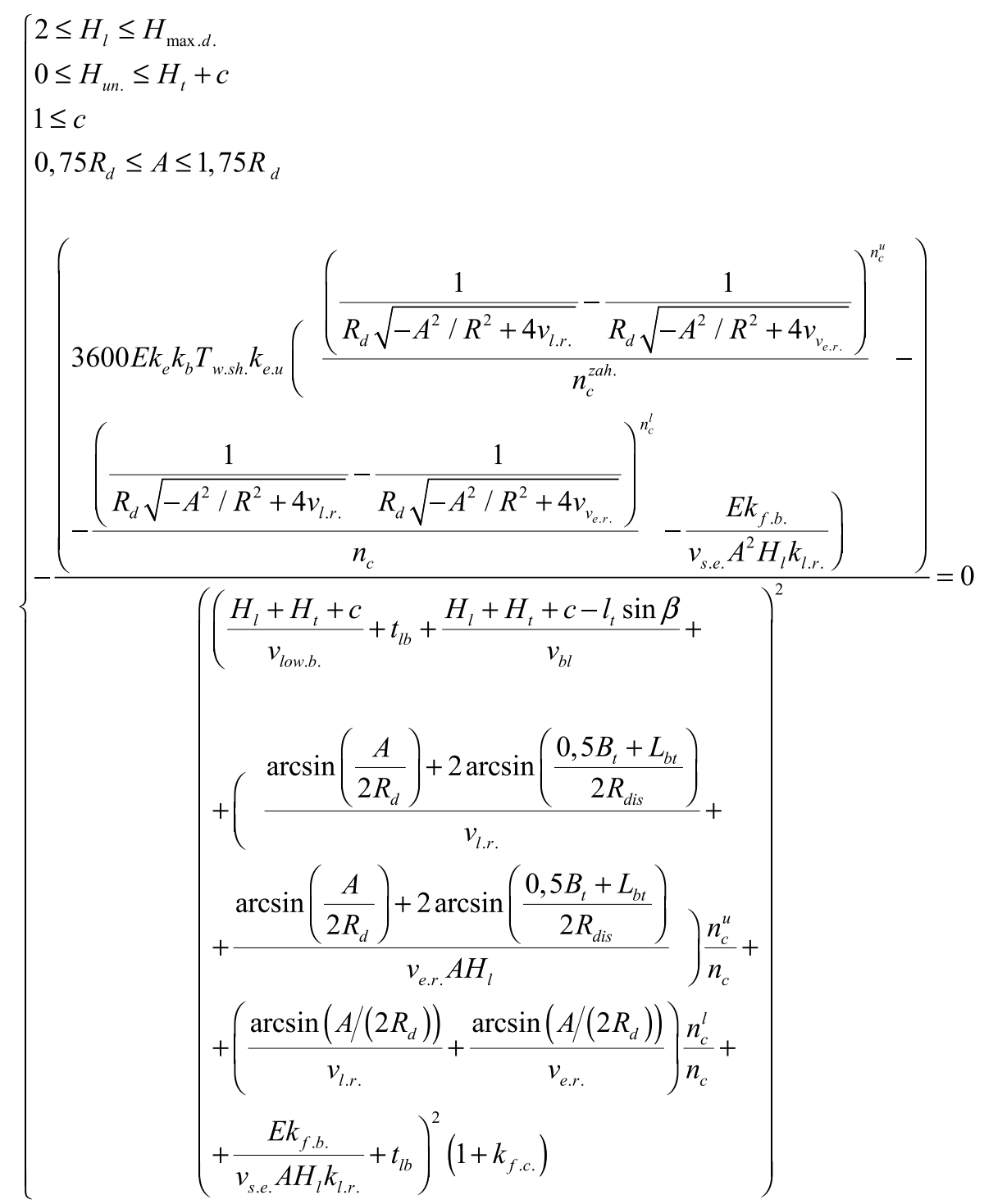

The implementation of the target function for the first and second processing schemes are possible, based on the study of the extreme values of the excavation block length at the interval from $50 \mathrm{~m}$ to a maximum value of the length or width of the standard area:

$$
\left\{\begin{array}{l}
2 \leq H_{o . l .} \leq H_{l .} \\
1 \leq b_{b} \leq \frac{E}{h b} \\
0 \leq B_{s . p .} \leq A \\
\left(\frac{e^{\frac{\ln (S)}{D_{f}}} H_{o l}}{b_{b} l_{t} \sin \beta n_{e . b .}}+\frac{B_{\text {s.p. }} L_{\text {s.p. }} H_{o l}}{b_{b} l_{t}^{2} \cos \beta \sin \beta}\right) \mathrm{E} \\
-\frac{L_{e . b}^{2} A H_{l} k_{l . r .}}{-}=0
\end{array}\right.
$$

Similarly, for the third technological scheme it is expedient to define an optimal parameter value of the length of the excavator block from a system of conditions: 


$$
\left\{\begin{array}{l}
2 \leq H_{o . l .} \leq H_{l .} \\
1 \leq b_{b} \leq \frac{E}{h b} \\
0 \leq B_{\text {s.p. }} \leq A \\
\frac{E e^{\frac{\ln (S)}{D_{f}}} H_{o l}}{L_{e . b}^{2} A H_{l} k_{l . r .} b_{b} l_{t} \sin \beta n_{e . b .}}=0
\end{array}\right.
$$

\section{Discussion of the Research Results}

When studying the performance of a hydraulic excavator, a number of factors are taken into account: the type and properties of the rock, the type of excavator, and the geometric parameters of the face and bucket of the excavator.

As a result of the performed research of humidity influence on the duration of unloading of a bucket of the Caterpillar $345 \mathrm{C}$ excavator with a Cat NACD bucket (see Table 1), it was found that the duration of the bucket unloading depends on the humidity content of the primary kaolin (the correlation coefficient is 0.88 ) and is analytically described by the second degree polynomial of the following form (see Figure 6):

$$
t_{r}=0,568+0,0406 v+0,0018 v^{2},
$$

where $v$ is the humidity content of primary kaolin in the array, $\%$.

The obtained results are correlated with the trends of decrease in excavation productivity with increasing rock humidity, which were observed in the research (Loginov, E., 2016, Kurekhin, E.V., 2009) and emphasize the importance of taking into account the influence of humidity on excavation productivity in the production of kaolin.

The results of the technological modeling of the dependence of the coefficient of the contact form on the

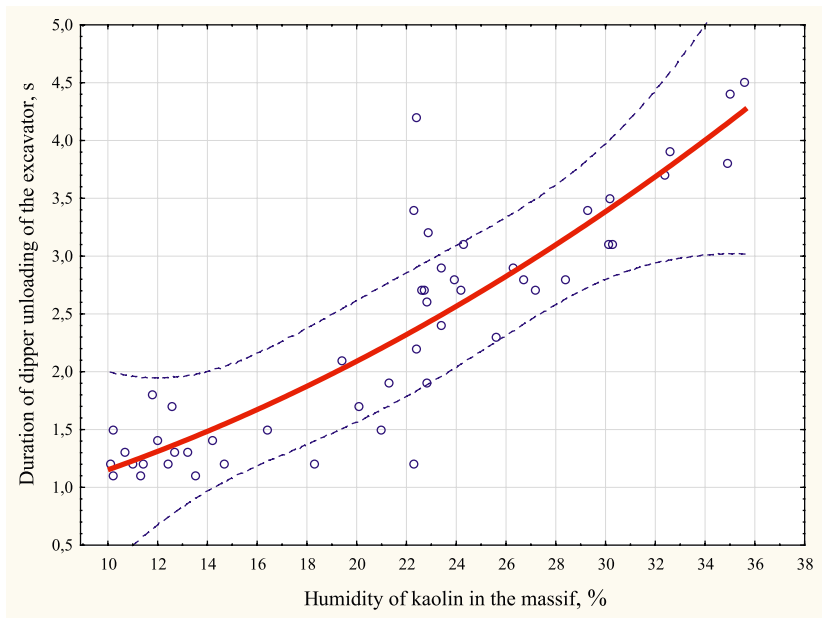

Figure 6: Dependence of duration of bucket unloading of the excavator on humidity of kaolin in the massif

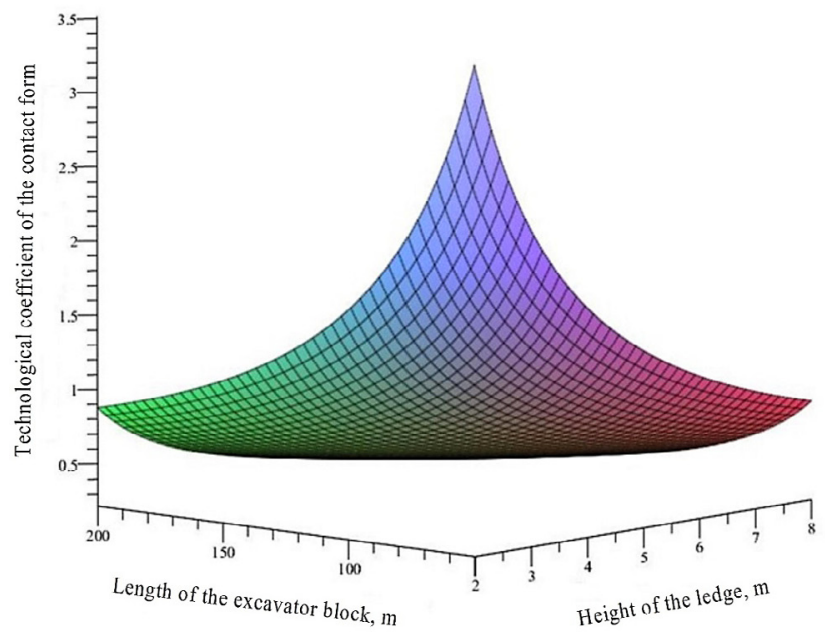

Figure 7: Dependence of the technological coefficient of the contact form on the length of the excavator block and the height of the ledge

length of the excavator block and the height of the ledge are shown in Figure 7.

A comparison of the results (see Figure 8) with the predicted performance values showed the presence of a significant correlation between the parameters that were studied $(r=0,7-0,9)$ and the presence of minor differences within $10 \%$.

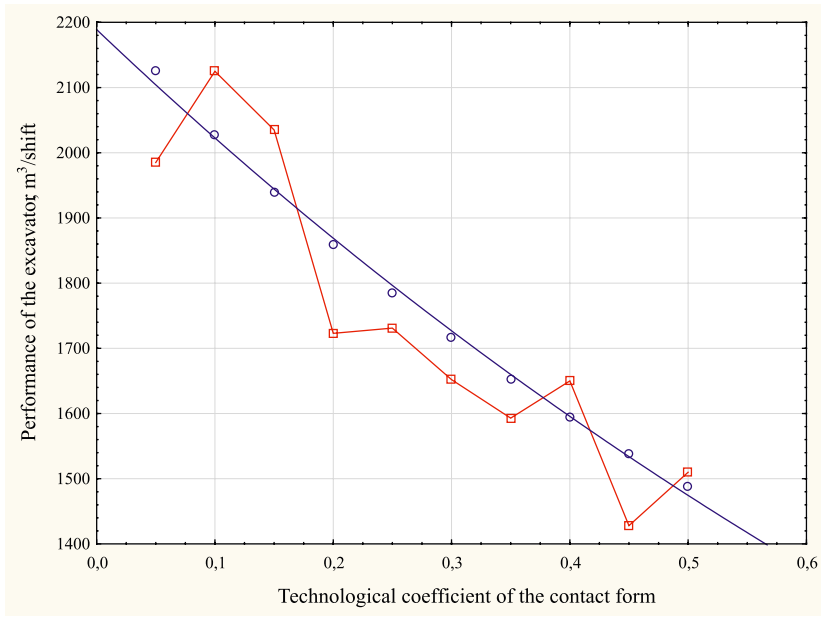

Figure 8: The dependence of the performance of the excavator from the technological coefficient of the contact form:

- theoretical values: - empirical values

For the variant of the technological scheme with a lower unloading excavator haul truck (scheme 1), the model based on the duration of a working cycle of the height of the ledge and the width of the excavator pass (see Figure 9) the use of which will allow for the choosing of the optimal technological parameters. The obtained simulation results correlate with the main trends obtained for brown coal deposits in the research (Tiulenev, M.A., et al., 2011) showing that the influence of the rock type and its properties are taken into account. 


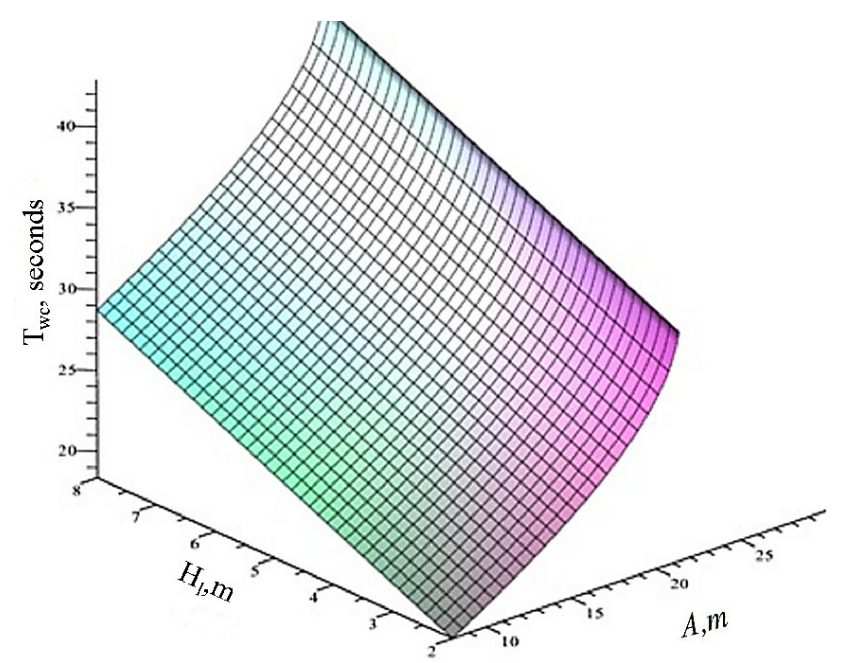

Figure 9: The dependence of the working cycle duration on the height of the ledge and the width of the excavator pass: $T_{W C}$ is the duration of the working cycle; $A$ is the width of the excavator pass; $H_{l}$ is the height of the ledge

The above considered technological scheme has several advantages: the simplicity of the production process, to minimize the effect of the lower layers' water content on the efficiency of rock mass transportation, minimum width of the transport berms and a number of other advantages.

However, the disadvantages include a slightly longer cycle time, which is due to the necessity of providing large angles of rotation for unloading.

An alternative to this approach is the use of a lower unloading or its combination with the upper unloading.

The resulting model will allow for the choosing of the optimal values of the technological parameters for different areas, depending on the value of the contact form technological coefficient.

The investigated results of technological schemes' parameterization of the hydraulic excavator use are comparable to the data received from the research of other mineral excavation effectiveness. In particular, several similar trends were established in the study of brown coal excavation productivity in face extraction areas (Tiulenev, M.A., et al., 2017).

\section{Conclusions}

1. The moisture content of the primary kaolin directly affects the duration of bucket unloading, and can be described analytically for the case studied as a second degree polynomial.

2. The procedure for assessing the performance of the primary kaolin excavation for the selective development of curved sections should include consideration of the area's shape fractal nature on the basis of the first proposed technological coefficient of the contact shape.
3. The allowance of the working cycle duration of backhoe excavators, the influence of curvilinear contours of the conditioned area and their fractal nature through the specific time of shifting can improve the reliability of forecasting performance.

4. Mathematical models of the primary kaolin excavation process on the curved face of the conditioned area excavator of a backhoe type are developed. The reliability of the proposed mathematical models of productivity is confirmed by the presence of minor differences between theoretical and empirical values within $10 \%$.

5. The results of these studies allow us to develop an optimal methodology for quality management, taking into account the spatial variability of the primary kaolin deposit's quality indicators and similar indicators of the variability of mining and minerals geological conditions.

\section{References}

Abdellah, W.R., Beblawy, M.M., Mohamed, M.T. (2018): Evaluation of open pit slope stability using various slope angles and element types. Mining of Mineral Deposits, 12, 2, 47-57. https://doi.org/10.15407/mining12.02.047.

Adibi, N., Ataee-pour, M. and Rahmanpour, M. (2015): Integration of sustainable development concepts in open pit mine design. Journal of Cleaner Production, 108, 1037-1049. https: //doi.org/10.1016/j.jclepro.2015.07.150.

Azapagic, A. (2004): Developing a framework for sustainable development indicators for the mining and minerals industry. Journal of cleaner production, 12, 639-662.

Brilli, M., Lapuente Mercadal, M.P., Giustini, F. and Royo Plumed, H. (2018): Petrography and mineralogy of the white marble and black stone of Göktepe (Muğla, Turkey) used in antiquity: New data for provenance determination. Journal of Archaeological Science: Reports, 19, 625-642. https://doi. org/10.1016/j.jasrep.2018.03.037.

Carabassa, V., Oriol O. and Josep M. Alcañiz (2019): RESTOQUARRY: Indicators for self-evaluation of ecological restoration in open-pit mines. Ecological Indicators, 102, 437-445. https://doi.org/10.1016/j.ecolind.2019.03.001.

Cheskidov, V. I., Norri, V. K., Zaitsev, G. D., Botvinnik, A. A., Bobyl'sky, A. S. and Reznik, A. V. (2014): Effectivization of open pit hard mineral mining. Journal of Mining Science, 50, 5, 892-903. https://doi.org/10.1134/S1062739114050081.

Chetverik, M., Bubnova, E. and Babiy E. (2013): The main technical solutions in rational excavation of minerals in open-pit mining. Annual Scientific-Technical Collection «Mining of Mineral Deposits», 173-176.

Drebenstedt, C., Singhal, R. (2013). Mine Planning and Equipment Selection: Proceedings of the 22nd MPES Conference, Dresden, Germany, 14th-19th October 2013. Springer Science \& Business Media. https://doi.org/10.1007/978-3-31902678-7.

Golik, V., Komashchenko, V., Morkun, V. and Gvozdkova, T. (2016): The theory and practice of rock massifs control in the ore mining. Metallurgical and mining industry, 1, 209-212. 
Grenon, M. and Hadjigeorgiou, J. (2010): Integrated structural stability analysis for preliminary open pit design. International Journal of Rock Mechanics and Mining Sciences, 47, 3, 450-460. https://doi.org/10.1016/j.ijrmms.2009.11.001.

Kapageridis, I. and Albanopoulos, C. (2016): Reserve estimation of a marble quarry using quality indicators. Bulletin of the Geological Society of Greece, 50, 4, 1849-1858. http://dx.doi. org/10.12681/bgsg.11924.

Komissarov, A.P., Shestakov, V.S. and Zhiganov, A.A. (2006): K obosnovaniyu rabochih i ekspluatatsionnyih harakteristik karernogo ekskavatora (To substantiation of working and operational characteristics of career excavator). Gornyiy informatsionno-analiticheskiy byulleten (nauchno-tehnicheskiy zhurnal), 5, 236-239. (in Russian without English abstract)

Koryakin, A.I., Voronkov, V.F. and Strelnikov, A.V. (2009): Eksperimentalnyie issledovaniya ekskavatornogo tsikla gidravlicheskih ekskavatorov $\mathrm{v}$ razlichnyih rezhimah rabotyi (Experimental studies of excavatory cycle of hydraulic excavators in different operating modes). Zhurnal «Vestnik Kuzbasskogo gosudarstvennogo tehnicheskogo universiteta», 5, 15-20. (in Russian without English abstract)

Krasilnikov, A. (2013). Formation of stable quality coal in open pit. Transbaikal state university journal, 1, 25-31.

Kurehin, E.V. (2009): K voprosu komplektatsii zemleroynopogruzochnoy tehniki pri razrabotke Kuzbasskih karerov maloy i sredney moschnosti (To question of complete set of excavation-loading equipment at development of Kuzbass opencasts of small and average capacity). Zhurnal «Vestnik Kuzbasskogo gosudarstvennogo tehnicheskogo universiteta», 3, 17-24. (in Russian without English abstract)

Kurlenya, M.V., Levin, V. S. and Shtele, V. I. (1983). Theory of mining technology. prospects of development. Journal of Mining Science, 19, 4, 317-325.

Loginov, E. (2016): Osobennosti ispolzovaniya ekskavatorovpogruzchikov (Features of the use of backhoe loaders). Nauchnyiy zhurnal, 6, 152-154. (in Russian with English abstract)

Manhart, A., Vogt, R., Priester, M., Dehoust, G., Auberger, A., Blepp, M., Dolega, P., Kämper, C., Giegrich, J., Schmidt, G. and Kosmol, J. (2019): The environmental criticality of primary raw materials - A new methodology to assess global environmental hazard potentials of minerals and metals from mining. Mineral Economics, 32, 1, 91-107.

Nenashev, A.S. and Fedotenko, V.S. (2011): Tehnologiya postroeniya skolzyaschego spuska s zadnim napolnitelem (The technology of constructing sliding descent with back filler). Zhurnal «Vestnik Kuzbasskogo gosudarstvennogo tehnicheskogo universiteta», 5, 23-27. (in Russian with English abstract)

Pobegaylo, P.A. (2014): Nekotoryie geometricheskie svoystva ploskogo trehzvennogo manipulyatora (Some geometrical properties of the flat three-unit manipulator). Gornyiy informatsionno-analiticheskiy byulleten (nauchno-tehnicheskiy zhurnal), 3, 1-28. (in Russian with English abstract)

Rakishev, B.R., Sashev, Yu.R., Lunkin, I.V. and Kurilo, V.N. (2000): Raspredelenie ob'emov rudyi v rezhime usredneniya (Distribution of ore volumes in the inter-averaging mode). Gornyiy informatsionno-analiticheskiy byulleten (nauchno- tehnicheskiy zhurnal), 11, 118-122. (in Russian with English abstract)

Shustov, O., Dryzhenko, A. (2016): Ustroystvo peregruzochnyih punktov kombinirovannyih vidov transporta pri razrabotke zhelezorudnyih mestorozhdeniy (Organization of dumping stations with combined transport types in iron ore deposits mining). Mining of Mineral Deposits, 10(2), 78-84. https:// doi.org/10.15407/mining 10.02.078. (in Russian with English abstract)

Sobko, B., Drebenstedt, C., Lozhnikov, O. (2017): Selection of environmentally safe open-pit technology for mining waterbearing deposits. Mining of Mineral Deposits, 11, 3, 70-75. https://doi.org/10.15407/mining11.03.070.

Sobolevskyi, R., Korobiichuk, V., Iskov, S., Pavliuk, I. and Kryvoruchko, A. (2016): Exploring the efficiency of applying fractal analysis for the process of decorative stone quality control. Eastern-European Journal of Enterprise Technologies, 6, 3, 32-40. https://doi.org/10.15587/1729-4061.2016. 85227.

Sobolevskyi, R., Vashchuk, O. and Tolkach, O. (2015): Development of methodology for assessing geospatial variability of primary kaolin. New Developments in Mining Engineering 2015. Theoretical and Practical Solutions of Mineral Resources Mining, 505-509.

Strelnikov, A.V. and Tiulenev, M.A. (2011): Opyit rabotyi na ekskavatorah na karerah OAO «UK Kuzbassrazrezugol» (Employment experience of backhoes at open-pit mines of OAO «UK Kuzbassrazrezugol»). Zhurnal «Vestnik Kuzbasskogo gosudarstvennogo tehnicheskogo universiteta», 2, 8-12 (in Russian without English abstract)

Taboada, J., Rivas, T., Saavedra A., Ordóñez, C., Bastante, F. and Giráldez, E. (2008): Evaluation of the reserve of a granite deposit by fuzzy kriging. Engineering Geology, 99, 1, 23-30. https://doi.org/10.1016/j.enggeo.2008.02.001.

Tyulenev, M., Litvin, O., Cehlár, M., Zhironkin, S., Gasanov, M. (2017): Estimation of hydraulic backhoes productivity for overburden removing at kuzbass open pits. Acta Montanistica Slovaca, 22(3), 296-302.

Tyulenev, M.A., Pronoza, V.G. and Strelnikov, A.V. (2011): Razrabotka modeley litsa dlya posloynogo opuskaniya transhey i razrabotka opuskaniya obratnyimi gidravlicheskimi lopatkami (Development of face patterns for layer-by-layer sinking of trenches and development of sinking by reverse hydraulic shovels). Gornyiy informatsionno-analiticheskiy byulleten (nauchno-tehnicheskiy zhurnal), 10, 7-14. (in Russian with English abstract)

Zairov, Sh., Ravshanova, M., Karimov, Sh. (2018): Intensification of technological processes in drilling and blasting operations during open-cut mining in Kyzylkum region. Mining of Mineral Deposits, 12, 1, 54-60. https://doi.org/10.15407/mining12.01.054.

Zelenskiy, A. S. (2002): Metodologicheskie osnovyi geodezicheskogo obespecheniya planirovaniya i ucheta gornyih rabot $\mathrm{v}$ informatsionnoy sisteme upravleniya rudnogo karera (Methodological bases of surveying support of planning and record-keeping of mining in information control system of an ore quarry). Nauchnyiy vestnik NGU. (in Russian without English abstract) 


\section{SAŽETAK}

\section{Optimizacija procesa upravljanja učinkovitošću primarnoga iskopavanja kaolina na zakrivljenoj površini kondicioniranoga područja}

Dokazan je utjecaj primarne vlage kaolina na trajanje istovara bačve, a dobivena je analitička ovisnost za procjenu ovoga odnosa u obliku polinoma drugoga stupnja. Članak nudi tri glavne tehnološke sheme za različite tehnološke uvjete i obrazlaže postupak ocjene produktivnosti primarnoga iskopa kaolina za slučajeve selektivnoga razvoja krivuljastih presjeka na temelju prvoga predloženog tehnološkog koeficijenta kontaktnoga oblika, koji uzima u obzir fraktalnu prirodu oblika područja. Prvi put se predlaže uključivanje određenoga vremena pomicanja u radnome ciklusu bagera rovokopača. Razvijeni su matematički modeli postupka iskopavanja primarnoga kaolina na zakrivljenoj površini kondicioniranoga područja bagerom rovokopačem za različite varijante međusobnoga rasporeda hidrauličnoga bagera i utovarivača.

\section{Ključne riječi:}

produktivnost, upravljanje učinkovitošću, kaolin, bager, fraktalna dimenzija

\section{Authors contribution}

Ruslan Sobolevskyi (Doctor of Science, professor, Head of the Department of Mine Surveying): leader of the field investigations on all presented localities; analysed, synthesized and interpreted field and laboratory data; wrote most of the text of the article. Valentyn Korobiichuk (Doctor of Science, professor): wrote most of the text of the article. Volodymyr Levytskyi (PhD, associate professor): participated in field investigations on all localities, providing guidelines for the manuscript, wrote the text of the article. Victor Pidvysotskyi (Doctor of Science, associate professor): collected data and analysed them for selection in this publication. Oleksandr Kamskykh (PhD, associate professor): collected data and analysed them for selection in this publication, wrote the text of the article; Liudmyla Kovalevych (senior teacher of the Department of Mine Surveying): collected data and analysed it for selection in this publication, wrote the text of the article. 